\title{
Limnology and aquatic fauna of EPP 173, Melaleuca Park, refuge for an outlier population of the Black-stripe minnow Galaxiella nigrostriata (Galaxiidae), in southwestern Australia
}

\author{
Brenton Knott' ${ }^{1}$, Edyta J. Jasinska ${ }^{1,2}$ and Kimberly D. Smith ${ }^{1,3}$ \\ ${ }^{\prime}$ Department of Zoology, The University of Western Australia, \\ 35 Stirling Highway, Crawley, WA, 6009, Australia: email: bknott@cyllene.uwa.edu.au \\ 2 Present address: Department of Biological Sciences, University of Alberta, \\ AB, T6G 2E9, Canada: email: edytaj@ualberta.ca \\ ${ }^{3}$ Present address: Murdoch University Centre for Fish and Fisheries Research, \\ Division of Science and Engineering, School of Biological Sciences and Biotechnology, \\ Murdoch University, Murdoch, WA 6150, Australia: email: ksmith@central.murdoch.edu.au
}

\begin{abstract}
The physicochemistry, hydrology and invertebrate fauna are described for an unusual wetland, EPP 173, in Melaleuca Park, near Perth, Western Australia. EPP 173 is important as the site for a northern outlier population of the Black-stripe minnow, Galaxiella nigrostriata (Shipway), a fish endemic to southwestern Australia. EPP 173 is an acid $(\mathrm{pH}<5.5$, typically $\mathrm{pH}$ 3.3 to 3.9 ), seasonal wetland with unusually dark water (TCU >1200). The colour of the water together with the surrounding forest and wetland vegetation facilitate the establishment and persistence of strong thermal stratification of the wetland in spring and summer. The invertebrate fauna comprises 41 species with a substantial benthic cladoceran component, including at least one species previously known only from southern wetlands between Augusta and Albany. The wetland is of high conservation value, containing no exotic species and low concentrations of nutrients accompanied by the absence of algal blooms. However, encroaching urban development is likely to alter the limnology of EPP 173, threatening the survival of the resident $G$. nigrostriata population.
\end{abstract}

Extra keywords: thermal stratification, disjunct distributions, aestivating fish, refugia, aquatic invertebrates.

\section{INTRODUCTION}

Galaxiella nigrostriata (Shipway, 1953), G. munda McDowall, 1978 (Galaxiidae), Lepidogalaxias salamandroides Mees, 1961 (Lepidogalaxiidae), and Nannatherina balstoni Regan, 1906 (Nannopercidae) are freshwater teleosts endemic to Western Australia, occurring in temporary, acidic, darkwater wetlands on peat flats between Augusta and Albany in the southwest of the State. Of these four species, three are also known from outlier populations north of their main area of distribution: G. nigrostriata, at Bunbury (Morgan et al. 1996, 1998) and EPP 173 in Melaleuca Park (Smith et al. 2002a; 2002b); G. munda, between Gingin and Muchea (Allen 1982, Morgan et al. 1996, 1998), and N. balstoni at Gingin (Morgan et al. $1996,1998)$. There is remarkably little biological divergence between the outlier and southern populations of $G$. nigrostriata, which are separated by a distance of $350 \mathrm{~km}$ (Smith et al. 2002a), while slight differences have arisen in morphology and genetics (Smith et al. (2002b).
The northern outlier population of G. nigrostriata occurs in wetland EPP 173 within Melaleuca Park (Figure 1), northeast of Perth. Although the aquatic environments throughout the Black-stripe minnow's distribution are similar, namely acidic, black-water, temporary swamps, the northern population experiences a warmer and more arid climate. Smith et al. (2002a) demonstrated that cool, bottom-water refugia provided by strong thermal stratification of the dark waters in EPP 173 enable the continuing survival of the northernmost population of $G$. nigrostriata. The purpose of this paper is to describe the limnology and setting of EPP 173 to help explain the presence of the northern most outlier population of G. nigrostriata at EPP 173 and to provide the environmental context for the biological (Smith et al. 2002a) and morphogenetic (Smith et al. 2002b) comparisons between the southern and outlier populations.

\section{Study Area}

Melaleuca Park covers approximately 3000 ha of 


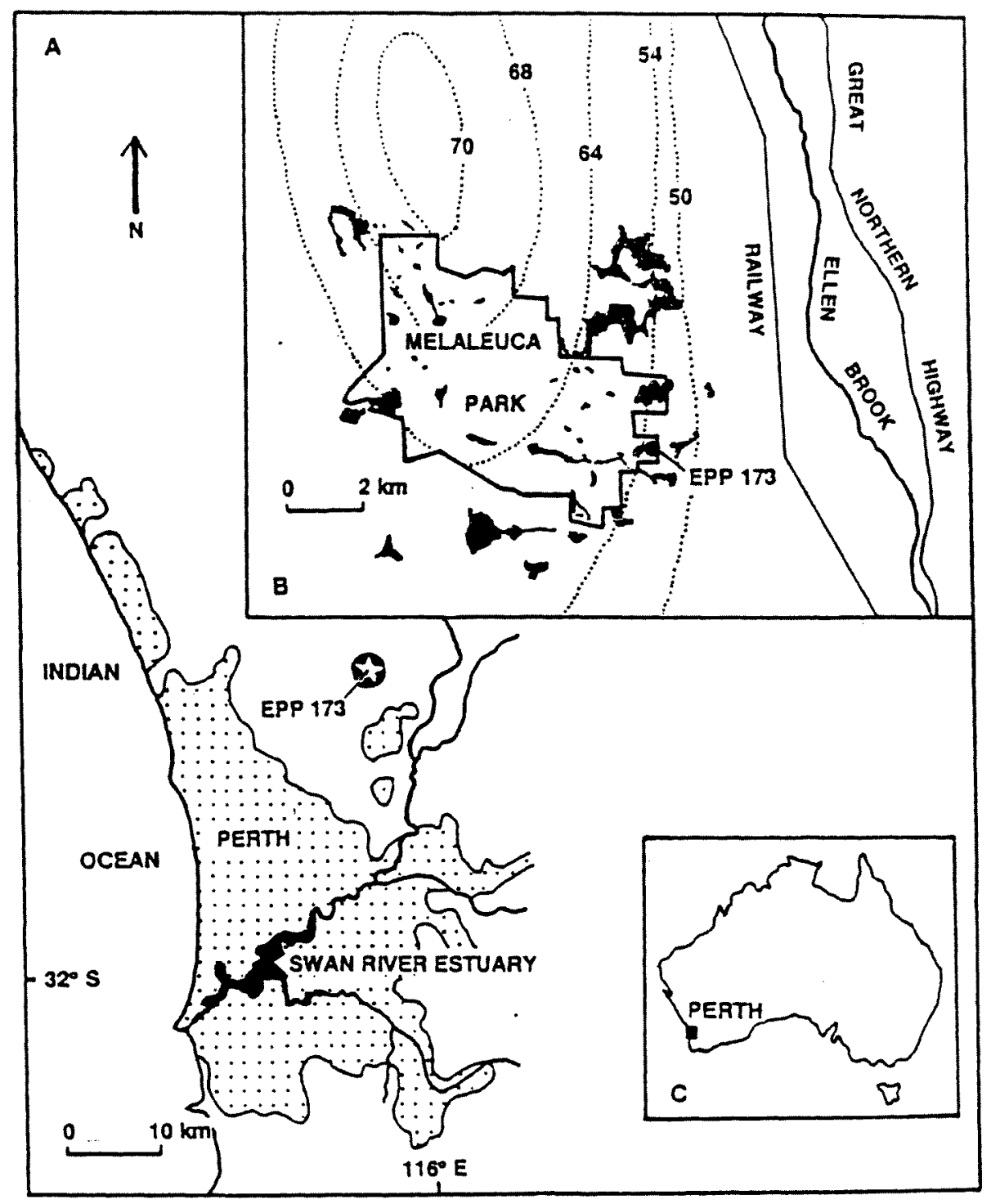

Figure 1 Map showing the location of: Melaleuca Park (A); EPP 173 on the eastern boundary of Melaleuca Park (B); and $(\mathrm{C})$, the general location of map 1A. A: centre of the star marks the location of EPP 173; stippling indicates urban areas; also shown are major lines of drainage lines into the Swan River estuary. B: dotted lines indicate water-table contours of the Gangara Mound, values in m Australian Height Datum; coarse stippling indicates wetlands in and near Melaleuca Park.

uncleared Crown Land (Department of Conservation and Environment 1983). It is situated on the siliceous sands of the Bassendean Dune geomorphic unit of the Swan Coastal Plain. The Park (Figure 1) lies within the eastern discharge area of the southern section of the Gnangara Mound, a complex of unconfined aquifers between the Swan and Moore Rivers (Davidson 1995). Melaleuca Park contains numerous wetlands disturbed, to varying degrees, by fire and/or human activity: a general description of the Park is given in Environmental Protection Authority (1998: Volume 2B, pp 146-148). The wetland harbouring G. nigrostriata, EPP 173 [un-named but number designated by Hill et al (1996)], is one of a complex of four swamps located on the eastern boundary of the Park: $31^{\circ} 42^{\prime} 22^{\prime \prime} \mathrm{S}, 115^{\circ} 57^{\prime} 48^{\prime \prime} \mathrm{E}$ (MK 016919) (Muchea Sheet, 2034-I SE, Australian 1:25000 Topographical Survey); elevation $50.41 \mathrm{~m}$ AHD (Australian Height Datum); area $\sim 1.5$ ha. The complex of four swamps appear, from aerial photographs, to be remnants of one, large ancestral swamp. On the northern perimeter of EPP 173 is a small wetland, designated here " $\mathrm{Mb}$ ", continuous with EPP 173 at high water levels. There is no surface drainage in the area other than a seasonal outflow creek from EPP 173. Of the four wetlands, EPP 173 alone receives a permanent groundwater discharge. This spring seepage, on the western side of the wetland, maintains an area of several square metres of standing water $(<11 \mathrm{~cm})$ over boggy peat overgrown with Baumea articulata (Cyperaceae), in 
late summer and autumn when the remainder of the wetland and the others nearby dry out completely. Springs are a common form of groundwater discharge from the eastern flanks of the Gnangara Mound where the highly porous Bassendean sands interdigitate with clays. The sediment profile in the centre of the wetland comprises a highly compacted superficial layer (7 $\mathrm{cm}$ deep) of fine organic peat; underlain by a mixture of sand and peat, with the peat content declining to $20 \mathrm{~cm}$ depth where it is replaced by coarse white sand with little or no organic material.

The climate is markedly seasonal, with hot summers and cool moist winters. Average day-time temperatures at Melaleuca Park are $31^{\circ} \mathrm{C}$ in summer and $18^{\circ} \mathrm{C}$ during winter. Average rainfall over the Gnangara Mound is $800 \mathrm{~mm}$ p.a. with $<5 \%$ falling in summer (Bureau of Meteorology, Perth, 1999). Average Class A pan evaporation of $1819 \mathrm{~mm}$ p.a. substantially exceeds the annual rainfall (Davis and Rolls 1987), but maximum evaporation rates occur when the wetland is dry except for the small area of standing water about the spring discharge. About Perth, droughts can last up to six months at a time (Newsome and Pickett 1993).

The surrounding vegetation of EPP 173 is dominated by open Banksia menziesii R. Br. woodland with low scattered marri (Corymbia calophylla R.Br.) and jarrah (Eucalyptus marginata Sm.) grading into a line of paperbark (Melaleuca preissiana Schau) around part of the margin of the wetland. Shore-parallel vegetation zones are most obvious along the eastern side of the swamp where the edge of the wetland is most clearly defined. Starting at the swamp edge, Leptocarpus sp. 1 (Restionaceae) grades into a mixed stand of the woody shrub Astartea fascicularis (Labill.) DC. and Leptocarpus sp. 2 with scattered specimens of another woody shrub, Calothamnus lateralis Lindley; the next band of vegetation the sedge Lepidosperma longitudinale Labill. (Cyperaceae) is separated by an area of open water from the central zone of the jointed twig-rush, Baumea articulata (R.Br. S.T. Blake) (Cyperaceae) which covers 0.7 ha or $47 \%$ of the total swamp area. The growth of L. longitudinale on columns $>21 \mathrm{~cm}$ high ('fire columns') indicates that at least part of the swamp has been burnt, and fire edges crossing the area of $B$. articulata are evident in aerial photographs. Western Australian Department of Conservation and Land Management (CALM) unpublished fire records show that the eastern sector of Melaleuca Park has been burnt twice since 1950 .

\section{MATERIALS AND METHODS}

EPP 173 was sampled on nine occasions, commencing 4 November, 1995. Water temperature and conductivity profiles were measured on 15
November, 1995, and 17 November, 1997, at two sites: site 1 - open water; site 2 - Baumea stand. An additional electrical conductivity profile was measured at site 1 on 16 December, 1998. Dissolved oxygen profiles were measured at the same two sites on 17 November, 1997. Dates of other water quality measurements taken at a single depth (10 $\mathrm{cm}$ ) are presented together with the data. The limnological parameters measured: water temperature using variously ORION Model 140 Conductivity and Salinity, or LF 95 WTW Conductivity, meters or immersing $\mathrm{Hg}$ thermometer with $0.1^{\circ} \mathrm{C}$ divisions; conductivity using a LF 95 WTW Conductivity Meter, dissolved oxygen using a Microprocessor Oximeter WTW OX 196; and pH using a LC80A meter.

Water samples were analysed for colour, $\mathrm{N}-\mathrm{NO}_{2}$; $\mathrm{N}-\mathrm{NO}_{3}, \mathrm{~N}_{-} \mathrm{NH}_{4}^{+}, \mathrm{P}_{-} \mathrm{PO}_{4}{ }^{3+}, \mathrm{Na}^{+}, \mathrm{K}^{+}, \mathrm{Ca}^{2+}, \mathrm{Mg}^{2+}, \mathrm{SO}_{4}^{2-}$, $\mathrm{Cl}$ and $\mathrm{HCO}_{3} / \mathrm{CO}_{3}{ }^{2 \cdot}$ by the Chemistry Centre (Western Australia).

Invertebrate fauna was sampled by 1 -minute-long sweeps with a $1 \mathrm{~mm}^{2}$ mesh net $(25 \mathrm{~cm} \times 25 \mathrm{~cm}$ frame). Four microhabitats - the outflow creek, central Baumea stand, more peripheral reeds (Lepidosperma) and ti-tree (Astartea) - were sampled on 4 November, 1995, and 17 November, 1997. Fauna samples were sorted live in the laboratory using dissecting microscope then preserved in $70 \%$ ethanol.

\section{RESULTS}

\section{Limnology}

During April-September, 1996 (late autumn to winter), no thermal stratification developed in EPP 173. Mid-day surface water temperatures of the open water during this coolest and wettest part of the year ranged from $12.8^{\circ} \mathrm{C}$ to $17.0^{\circ} \mathrm{C}$ (average $=14.4 \pm 1.3 \mathrm{SD}$ ). With the onset of warm days, such as $24.6^{\circ} \mathrm{C}$ (early afternoon air temperature) on November 15 (1995) and $27.2^{\circ} \mathrm{C}$ on November 17, 1997, a seep temperature gradient developed within the water column (Figure 2). The greatest drop in temperature, of $8.8^{\circ} \mathrm{C}$, occurred in the uppermost $10 \mathrm{~cm}$ of the water column (Figure $2)$. The bottom waters ( $>20 \mathrm{~cm}$ depth) generally remained at around $15^{\circ} \mathrm{C}$ (Figure 2).

Electrical conductivity profiles varied but not consistently with variations in depth even when temperature gradients had developed. There was a slight increase from 360 to $380 \mathrm{mS} / \mathrm{cm}$ with depth on 15 November, 1995 (Figure 3). However, conductivity values decreased from $500 \mathrm{mS} / \mathrm{cm}$ (surface) to $397 \mathrm{mS} / \mathrm{cm}$ (bottom) on 17 November, 1997. On the 16 December temperature decreased from $26^{\circ} \mathrm{C}$ at the surface to $20^{\circ} \mathrm{C}$ at the bottom $(40$ $\mathrm{cm}$ ), conductivity, however, was constant and slightly higher than $500 \mathrm{mS} / \mathrm{cm}$ (Figure 3). 


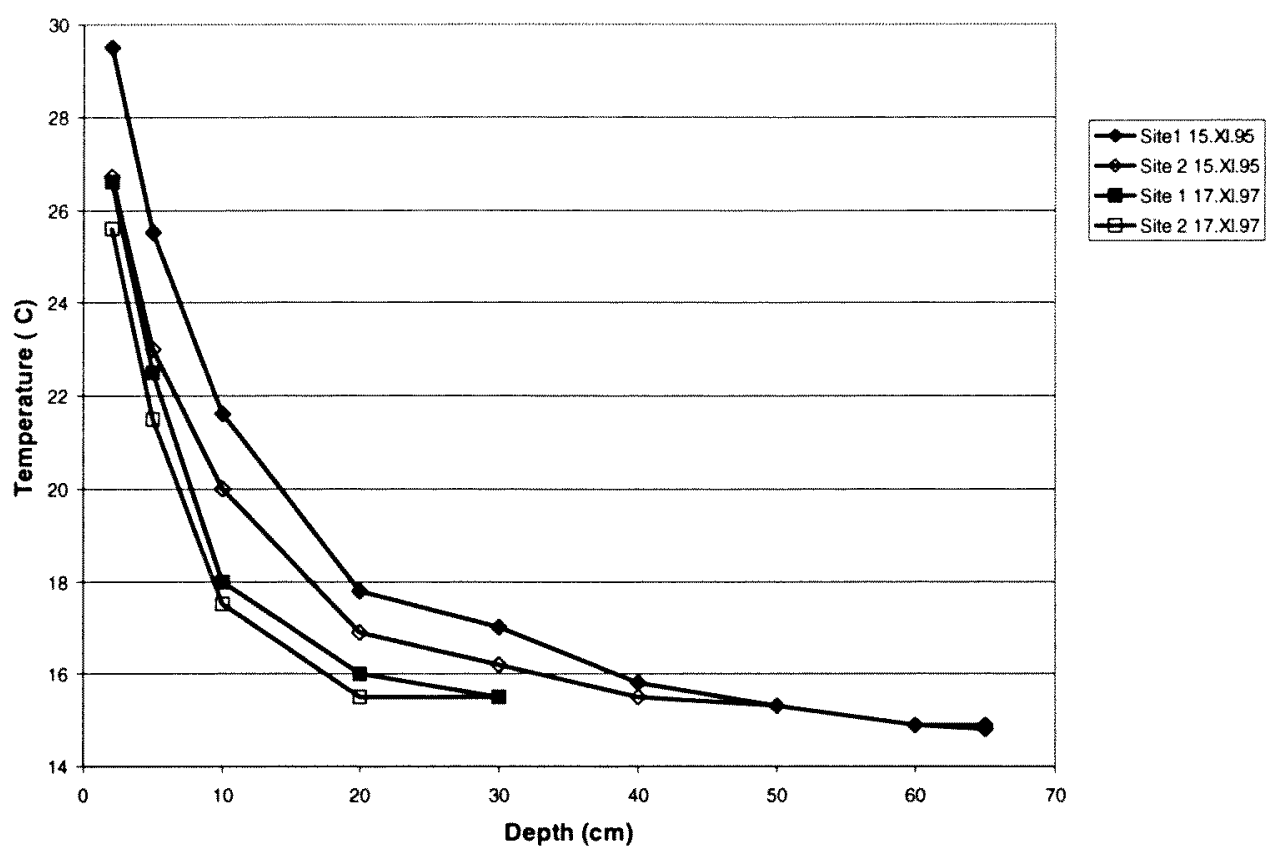

Figure 2 Temperature profile in EPP 173 in November 1995 and 1997. Each temperature and conductivity profile was taken from the water surface to the bottom of the water column - the different lengths for each curve representing different depths of each sampling site within the wetland. Upper four curves represent conductivity while water temperature is shown by the lower four curves.

Dissolved oxygen profiles were measured on 17 November, 1997, at the same sites as the temperature profiles. The DO gradient reflected that of temperature. Oxygen saturation was: highest at 70 to $80 \%(5.5$ to $6.75 \mathrm{mg} / \mathrm{L})$ in the uppermost 10 $\mathrm{cm}$; between 50 to $60 \%$ (through the depths $10-30$ $\mathrm{cm}$; and around $40 \%(4.4 \mathrm{mg} / \mathrm{L})$ at the bottom $(28$ cm depth).
EPP 173 was highly acidic, usually $\mathrm{pH} 3.3-\mathrm{pH}$ 3.9 except following episodes of heavy rainfall as in August, 1996, and December, 1998, when it had risen above $\mathrm{pH} 5$ (Figure 3). On every sampling occasion, $\mathrm{pH}$ was uniform through the water column.

Ionic composition of the water (Table 1) reflects seawater ionic dominance, and little departure from

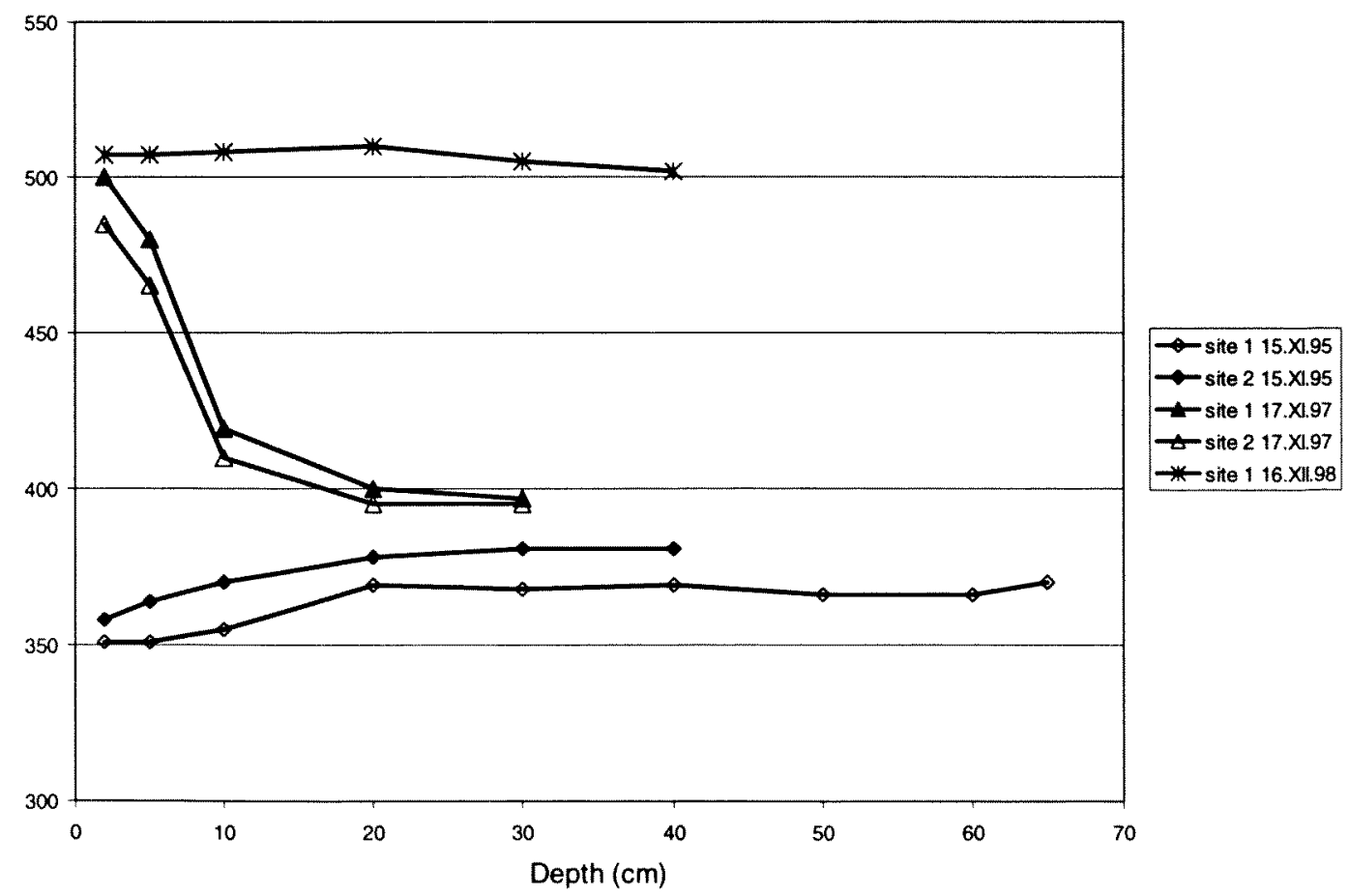

Figure 3 Electrical conductivity profiles in EPP 173 between November 1995 and December 1998. 
Table 1 Ionic dominance series ( $\mathrm{mEq} \%$ ) for EPP 173 (averages \pm SD of data collected on 17 Oct 97 , 27 Nov' 97 and 16 Dec '98) and for sea water.

\begin{tabular}{|c|c|c|c|c|}
\hline & $\mathrm{Na}^{+}$ & $\begin{array}{l}\text { Anions } \\
\mathrm{Mg}^{2+}\end{array}$ & $\mathrm{Ca}^{2+}$ & $\mathrm{K}^{+}$ \\
\hline EPP 173 & $78 \pm 13.9$ & $17 \pm 1.7$ & $3 \pm 0.6$ & $2 \pm 1.2$ \\
\hline Sea water* & 77 & 17.6 & 3.3 & 1.6 \\
\hline & & Cations & & \\
\hline & $\mathrm{Cl}^{-}$ & $\mathrm{SO}_{4}{ }^{2-}$ & \multirow{2}{*}{\multicolumn{2}{|c|}{$\begin{array}{c}\mathrm{CO}_{3}^{2-}+\mathrm{HCO}_{3} \\
0.8 \pm 0\end{array}$}} \\
\hline $\begin{array}{l}\text { EPP } 173 \\
\text { Sea water* }\end{array}$ & $\begin{array}{c}91.2 \pm 10.4 \\
90.4\end{array}$ & $\begin{array}{c}8.0 \pm 0 \\
9.3\end{array}$ & & 0.3 \\
\hline
\end{tabular}

*Bayly and Williams, 1973

seawater milli-equivalent proportions. However, unlike seawater, due to the much lower concentrations of ions in the freshwater EPP 173 , the resulting final concentrations of $\mathrm{CO}_{3}{ }^{2-} / \mathrm{HCO}_{3}$ were very low indicating a correspondingly low buffering capacity.

EPP 173 water was exceptionally dark, with ${ }^{3} 1200$ TCU at times late in the year [for example on 4 November, 1995 (when the Secchi disc depth was $13 \mathrm{~cm}$, of a total water depth of $65 \mathrm{~cm})], 17$ October, 1997, and 16 December, 1998). However, early in the year immediately following inundation the water on one occasion was noted (but not measured) to be scarcely coloured.

Phosphorus levels were low in EPP 173: total phosphorus $0.03 \mathrm{mg} / \mathrm{L}$, phosphate $0.02 \mathrm{mg} / \mathrm{L}$. Nitrogen concentrations were: ammonium $0.21 \mathrm{mg} /$ $\mathrm{L}$, nitrate $<0.02 \mathrm{mg} / \mathrm{L}$ and total nitrogen $2.3 \mathrm{mg} / \mathrm{L}$. Chlorophyll levels were very low: chlorophyll ' $a$ ' $<0.001 \mathrm{mg} / \mathrm{L}$, chlorophyll ' $\mathrm{b}$ ' $=0.003 \mathrm{mg} / \mathrm{L}$, chlorophyll ' $\mathrm{C}$ ' $=0.004 \mathrm{mg} / \mathrm{L}$, phaeophytin $=0.012$ $\mathrm{mg} / \mathrm{L}$.

\section{Invertebrate fauna}

In all, 41 species of invertebrates were recorded from EPP 173 (Table 2). The most abundant and diverse subset of the fauna were the cladocerans which comprised nine of the 41 species. Eight of the cladocerans were benthic dwelling species (Macrothricidae and Chydoridae). The most species-rich habitats were submerged ti-tree (Astartea fascicularis) and the reeds (Lepidosperma longitudinale) while the central Baumea stand had the lowest number of species. The late-summer pool about the spring outflow harbours odonatan nymphs but is not utilised by the minnow (Smith et al. 2002a).

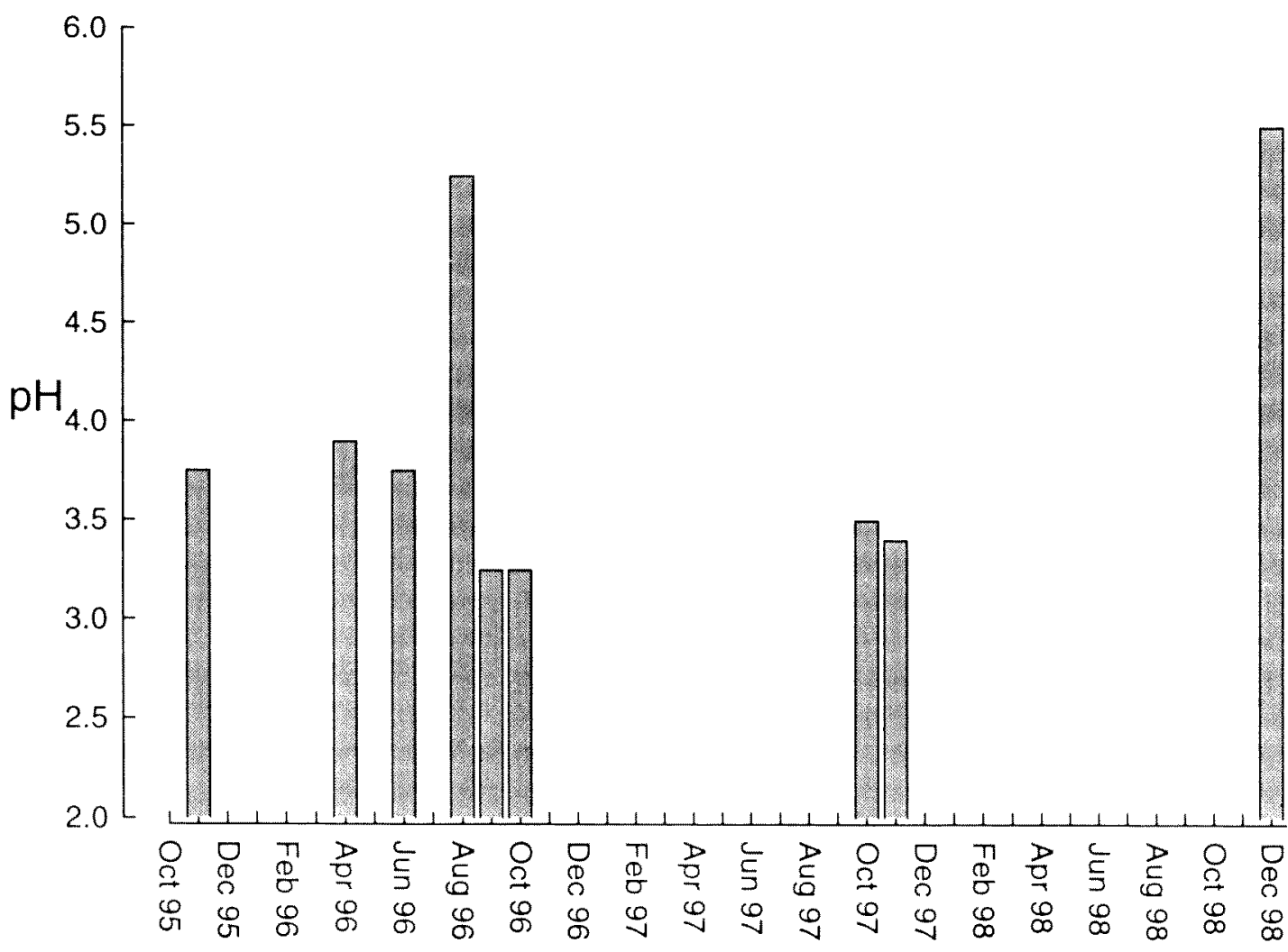

Figure $4 \mathrm{pH}$ values of EPP 173 water, 1995 to 1998 
Table 2 Invertebrate fauna collected from EPP 173 in the springs of 1995 and 1997.

\begin{tabular}{lccccc}
\hline Taxa & Baumea & ti-tree & reeds & creek & $\begin{array}{c}\text { Total \# of } \\
\text { occurrences }\end{array}$
\end{tabular}

\section{CRUSTACEA}

\section{Cladocera}

llyocryptus sp. 1

Scapholeberis kingi (Sars 1903)

Alonella clathratula Sars 1888

Biapertura setigera (Brehm 1931)

Biaperura rigidicaudis (Smirnov 1971)

Graptoleberis testudinaria (Fischer 1848)

Monope reticulata (Henry 1922)

Rak obtusus (Smirnov and Timms 1983)

? gen. nov. (closest to Rhynchochydorus)

\section{Copepoda}

Calamoecia tasmanica (Smith 1909)

Mesocyclops sp. 1

Paracyclops sp. 1

Ostracoda

Ilyodromus sp. 1

Decapoda

Cherax quinquecarinatus (Gray, 1845)

INSECTA

\section{Diptera}

Chaoborinae sp. 1

Alotanypus dalyupensis (Freeman 1961)

Harrisius sp. 1

Limnophyes pullulus (Skuse 1989)

Paramerina parva (Freeman 1961)

Tanytarsus sp. 1

\section{Coleoptera}

Antiporus sp. 1

Dryopidea sp. 1

Hydrochus sp. 1

Hydrophilidae

Hyphydrus elegans (Montrouzier 1860)

Limnodessus sp. 1

\section{Hemiptera}

Sigara (Tropocorixa) mullaka Lansbury 1970

Gerridae sp. 1

Hebriidae sp. 1

Vellidae sp. 1

\section{Odonata}

Austrolestes io (Selys 1862)

Austroagrion coeruleum (Tillyard 1908)

Austrogomphus sp. 1

Austrolestes analis (Rambur 1842)

Trichoptera

Leptoceridae sp. 1

Leptoceridae sp. 2

OLIGOCHAETA: Naididae

Pristinella jenkinae (Stephenson 1931)

NEMATODA spp 1

TOTAL

14

23

24




\section{DISCUSSION}

In terms of ionic dominance and equivalent proportions, the ionic pattern of EPP 173 is typical of many surface waters on the Swan Coastal Plain (Williams 1967), indicative of both the seawater origin of the water and of little geochemical modification, consistent with movement of groundwater through chemically unreactive siliceous Bassendean sands underlying the wetland. Indeed, in terms of the ionic pattern and conductivity and $\mathrm{pH}$ values, the water properties of EPP 173 were similar to those of the southern wetlands containing $G$. nigrostriata populations (Smith 1996). The most notable and unusual feature of EPP 173 is its very dark water colour during spring and summer which provides the conditions for the development of a pronounced temperature stratification of the water column. Davis and Rosich (1993) suggested that water of Swan Coastal Plain swamps with colour values $352 \mathrm{~g}_{440} \mathrm{~m}^{-1}$ or $300 \mathrm{HU}$ should be classified as coloured. Conversion of the TCU ( $\cong$ Gilvin) values for EPP 173 swamp gives an $\mathrm{HU}$ value $>6900$ [following the conversion of Kirk (1983: p.56) cited by Schmidt and Rosich (1993: p.42)], considerably higher than the maximum HU values $<600$ for Swan Coastal wetlands cited by Schmidt and Rosich (1993) including the seven dark water swamps about Perth in the Growns et al. (1993) study.

This temperature stratification, resulting from the interaction between solar heating and light attenuation in highly coloured water, is crucial for the retention of the minnow in EPP 173 (Smith et al. 2002a). Ryder and Horwitz (1995) observed transient temperature gradients of up to $6.6^{\circ} \mathrm{C}$ in Lake Jandabup despite the lake being only slightly coloured (2 to $17 \mathrm{~g}_{440} \mathrm{~m}^{-1}$ ) (Sommer and Horwitz, 1999). They suggested that the establishment of temperature gradients could be a feature of all dark-water lakes on the Swan Coastal Plain. In order to maintain the population of G. nigrostriata in EPP 173, the temperature stratification must be reliable and stable against wind mixing during the daytime; due to cool overnight temperatures the stratification is unlikely to persist through the night. To mix an open lake the size of EPP 173 would require prevailing winds of $5 \mathrm{~ms}^{-1}$ for $14 \mathrm{hrs}, 7.5 \mathrm{~ms}^{-1}$ for 5 hrs, or $10 \mathrm{~ms}^{-1}$ for 2 hrs (pers, comm., Dr D Horn). Some wind data are available from nearby weather stations at Perth airport and Pearce airbase, however these do not report wind speed continuously and cannot be compared to these thresholds. Winds exceeding $21 \mathrm{kmh}^{-1}\left(5 \mathrm{~ms}^{-1}\right)$ are common at both stations but are unlikely to blow at this velocity for periods anywhere near 14 hours; the southwesterly sea-breeze, a dominant feature of the climate of southwestern Australia, is an afternoon phenomenon of not $>6$ hours duration. We do not see wind mixing as an immediate threat to the thermal stratification and subsequently to the G. nigrostriata population in EPP 173; however, the emergent and surrounding vegetation need to be maintained.

EPP 173 is a wetland of major conservation significance, harbouring a population of $G$. nigrostriata some $350 \mathrm{~km}$ north of the main area of distribution of the species. In terms of invertebrate fauna it has an unusually high (22\%) proportion, of benthic cladocerans which compares to $" 14 \%$ for other Swan Coastal Plain wetlands reported on by Growns et al. (1993). One of the EPP 173 cladoceran species (Rak obtusus) also represents a northern outlier population with a similar distribution to $G$. nigrostriata. Another chydorid cladoceran from this wetland could not be keyed out, even to genus, and is likely to be a new species. This rich benthic cladoceran fauna, a major component of the diet of the resident Black-stripe minnow, (Smith 1996) possibly contributed to the persistence of this northern population. The total of 41 species is within the range (34-61) of species recorded from the seven dark-water swamps in the Growns et al. (1993) study of 40 lakes on the Swan Coastal Plain near Perth. EPP 173 was somewhat unusual, compared to other Swan Coastal Plain wetlands, in that it contained no molluscs and only a single ostracod species - this is most likely a reflection of the low $\mathrm{CaCO}_{3}$ concentrations of this wetland. The remaining fauna of EPP 173 was similar to that of other wetlands of the Swan Coastal Plain (Growns et al. 1993). Further, unlike many other wetlands of the Swan Coastal Plain, EPP 173 is still in a relatively pristine condition with no exotic fauna, low nutrient levels and an absence of algal blooms. The very low abundance of microalgae was especially well illustrated by the very low chlorophyll and phaeophytin concentrations measured in the present study.

Given the importance of the special ecophysiological conditions operating in EPP 173, how likely is the wetland to continue operating with its present limnological pattern in the face of increasing urbanisation along the North East Corridor? Details of the hydrological cycle are unknown, even of the relative contributions from rainfall directly and groundwater. However, the shift to much more intense land use and increasing urbanisation generally through the area will inevitably mean greater: human intrusion, environmental degradation, fire frequency and destructiveness than is occurring now. Consequently, the hydrological cycles driving the limnology of EPP 173 will undoubtedly alter, increasing the probability for extinction of the resident population of $G$. nigrostriata. Tumulus springs, also dependent on groundwater discharge and once common along nearby Ellen Brook valley, are reduced to three structures; their importance 
stems from their provision of a specialised microenvironment which harboured northern outlier populations of moisture-dependent animals and plants within the xeric climate of the mid-Swan Coastal Plain (Knott and Jasinska 1998).

\section{ACKNOWLEDGEMENTS}

We sincerely acknowledge help from: Sharon Stratico and Jeff Kite, Water and Rivers Commission, Perth; and from David Horn, Centre for Water Research, The University of Western Australia, for kindly calculating the wind velocities required to mix EPP 173 on warm summer days. Funding from Rivers and Waters Commission, and the Department of Zoology, The University of Western Australia, is also acknowledged.

\section{REFERENCES}

Allen, G.R. (1982). A Field Guide to Inland Fishes of Western Australia. Western Australian Museum, Perth. 86 pp.

Bayly, I.A.E. and Williams, W.D. (1973). Inland Waters and their Ecology. Longmans, Camberwell, Australia. $316 \mathrm{pp}$.

Davidson, W.A. (1995). Hydrogeology and groundwater resources of the Perth region, Western Australia. Geological Survey of Western Australia, Bulletin 142: 1257.

Davis, J.A. and Rolls, S.W. (1987). A baseline biological monitoring program for the urban wetlands of the Swan Coastal Plain, Western Australia: Seasonal variation in the macroinvertebrate fauna and water chemistry of five Perth lakes. Environmental Protection Authority (WA)/ Water Authority of Western Australia, Perth. Bulletin 265.

Davis, J.A. and Rosich, R.S. (1993). Executive summary. In J.A. Davis, R.S. Rosich, J.S. Bradley, J.E. Growns, L.G. Schmidt and F. Cheal (eds), Wetlands of the Swan Coastal Plain: 6: 7-15. Water Authority of Western Australia, Perth.

Department of Conservation and Environment (1983). Conservation reserves for Western Australia as recommended by the Environmental Protection Authority -1983. The Darling System - System 6. Part II: Recommendations for specific localities. Department of Conservation and Environment, Perth.

Environmental Protection Authority (1998). Perth's Bushplan. Environmental Protection Authority, Perth.

Growns, J.E., Davis, J.A., Cheal, F. and Bradley, J.S. (1993). Classification of the wetlands using invertebrate data. In J.A. Davis, R.S. Rosich, J.S. Bradley, J.E. Growns, L.G. Schmidt and F. Cheal (eds), Wetlands of the Swan Coastal Plain: 6: 88-156. Water Authority of Western Australia, Perth.

Hill, A.L., Semeniuk, C.A., Semeniuk, V. and Del Marco, A. (1996). Wetlands of the Swan Coastal Plain. Vol. 1: Wetland Mapping, Classification and Evaluation-Main
Report. Vol. 2: Wetland Mapping, Classification and Evaluation - Wetland Atlas. Report prepared for the Water and Rivers Commission and the Department of Environmental Protection, Western Australia.

Knott, B. and Jasinska, E.J. (1998). Mound springs of Australia. In L. Botosaneanu (ed.), Studies in Crenobiology. The Biology of Springs and Springbrooks: pp 23-38. Backhuys Publishers, Leiden.

Morgan, D.L., Gill, H.S. and Potter, I.C. (1996). The distribution of freshwater fish in the south-western corner of Australia. Water and Rivers Commission Report WRT4, Perth.

Morgan, D.L., Gill, H.S. and Potter, I.C. (1998). The distribution, identification and biology of freshwater fishes in south-western Australia. Records of the Western Australian Museum. Suppl. No. 56, 97 pp.

Newsome, J.C. and Pickett, E.J. (1993). Palynology and palaeoclimatic implications of two Holocene sequences from southwestern Australia. Palaeogeography, Palaeoclimatology, Palaeoecology 101: 245-265.

Ryder, D.S. and Horwitz, P. (1995). Diurnal stratification of Lake Jandabup, a coloured wetland on the Swan Coastal Plain, Western Australia. Journal of the Royal Society of Western Australia 78: 99-101.

Schmidt, L.G. and Rosich, R.S. (1993). Physical and chemical changes and processes. In J.A. Davis, R.S. Rosich, J.S. Bradley, J.E. Growns, L.G. Schmidt and F. Cheal (eds), Wetlands of the Swan Coastal Plain: 6: pp 29-80. Water Authority of Western Australia, Perth.

Smith, K.D. (1996). An outlying population of Galaxiella nigrostriata (Pisces: Galaxiidae) at Melaleuca Park, Western Australia: Causes of habitat fragmentation. Honours thesis, Department of Zoology, The University of Western Australia. 115 pp.

Smith, K., Knott, B. and Jasinska, E.J. (2002a). Biology of the Black-stripe minnow, Galaxiella nigrostriata (Shipway), in an acidic, black-water lake in Melaleuca Park near Perth, Western Australia. Records of the Western Australian Museum 21: 277-284.

Smith, K., Penn, L. and Knott, B. (2002b). Genetic and morphological study of the Black-stripe minnow, Galaxiella nigrostriata (Shipway, 1953) (Salmoniformes: Galaxiidae), including a disjunct population near Perth, Western Australia. Records of the Western Australian Museum 21: 285-290.

Sommer, B and Horwitz, P (1999). Annual report for the wetland macro-invertebrate monitoring program of the Gnangara Mound Environmental Monitoring Project. Summer/autumn 1997 - 1998, spring 1998 and summer/ August 1998 - 1999. Final report to the Water and Rivers Commission of Western Australia. 61pp.

Williams, W.D. (1967). The chemical characteristics of lentic surface waters in Australia: A review. In A.H. Weatherley (ed.), Australian Inland Waters and their Fauna; Eleven Studies: 18-77. Australian National University Press, Canberra.

Manuscript received 25 July 2001; accepted 29 May 2002 